\title{
Erratum für: Bronder, Spiel, Zufall und Kommerz, DOI 10.1007/978-3-662-48829-4
}

Die Originalversion von Kapitel 2 wurde revidiert: Die Abbildung 2.1a war nicht korrekt. Die korrekte Abbildung 2.1a ist:
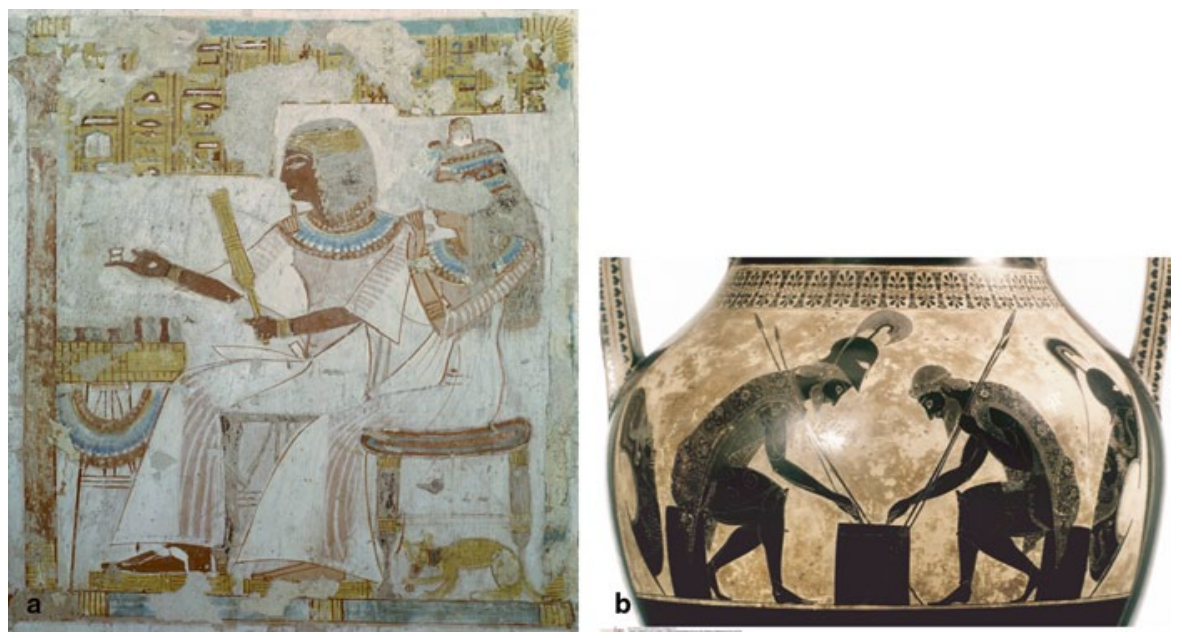

Abb. 2.1 Brettspiele a) im alten Ägypten, b) im alten Griechenland. a ๑ picture alliance/akg-images/André Held, b @ INTERFOTO/ Granger, NYC 